Criação / Tapeçaria 


\section{Iberê e a tapeçaria}

\section{MARLA ANGELA DE ALMEIDA MAGALHÄES}

I berê Camargo, gaúcho de Restinga Seca - o maior pintor brasileiro vivo - é uma pessoa comprometida até as últimas conseqüências com a sua verdade. Vive de escolhas nítidas - nunca se viu Iberê em posiçóes dúbias, buscando agradar ao que não lhe é agradável. De outro lado, náo há dúvida na opinião que se tem a respeito dele e de sua obra: é amar ou rejeitar. Porque, fiel a si mesmo, na vida e na arte, uma e outra têm a marca indelével de seu caráter.

Uma noite, nos anos 70, atendi a um telefonema, em que ele ia direto ao assunto. Vira uma exposiçáo de tapeçarias na Galeria Grupo B, ao lado do seu ateliê, e pensava em fazer a experiência. Gostaria de mostrar-me um desenho erótico que havia feito. Tenho que ver disse eu - embora seduzida pela idéia de trabalhar com ele, estava assustada com o tema. Imagine a possibilidade do grotesco! A tapeçaria era, para mim, uma versão do cartão - outra forma de ver a mesma coisa. Em épocas distintas, artistas como Goya, Corot, Calder, Chagall, aventuraram-se nela. Mas, tapeçaria erótica?

No dia seguinte, à noite, estava em sua casa, levada por amigos comuns. A sala de um pequeno apartamento, em Botafogo, era possuída por três enormes telas parecendo ocupar mais espaço do que nós, as pessoas que ali estávamos, vivas, nos mexendo, falando, sem contudo ter a metade da intensidade delas. Iberê nos mostrou uma série de desenhos e, finalmente, o que escolhera. $O$ assunto era forte, mas tratado com talento. Eu fiz a tapeçaria.

Neste tempo, assisti, diversas vezes, ao Iberê no exercício mental, emocional e físico de criar: a concentração, a tensāo, a energia, a entrega ao que ia surgindo na tela. $O$ não correspondente ao que queria e precisava, era apagado, sem pena. A tarefa era de muita procura - garimpeiro de si mesmo, ele năo fazia por menos: buscava diamantes.

Certa vez, uma noite em que Mário Carneiro filmava um curta metragem sobre sua obra no ateliê de Porto Alegre, ele fez e desfez por dezessete vezes o mesmo quadro. Às seis horas da manhã - exauridos todos - teve a tela arrancada do cavalete e pendurada em uma parede, por Maria, sua mulher. Acordando, lá pelas dez horas, voltou ele ao ateliê e, de novo, desmanchou grande parte do trabalho. E nunca mais 
pôde recomeçá-lo. A modelo convocada à pose adoecera, doença séria, na cama por mais de um mês. Por á́, o desejo já o havia deixado. As dezessete versóes do quadro só existem no filme de Mário.

Tais rigor e exigência que fazem de Iberê um pintor especial, vivi ao fazer as tapeçarias. Tirar do concretíssimo da lă a cor impossível, inventada no exercício da liberdade do artista - da certeza de que aquela, e nenhuma outra mais, seria a necessária para aquele espaço. $O$ buraco de uma agulha é o símbolo da dificuldade, do limite, que separa o que pode, do que, o que nunca poderá. $\mathrm{E}$, por ele, deveríamos passar mil fios, tantos quantos necessários à idéia da cor. Eram fios divididos de lá pura, misturados à seda, ao algodão, às texturas rústicas, às mais delicadas e finas linhas de bordar. Sem preconceito, buscando a composiçáo da cor, já que, no que fazíamos, a cor era o principal desafio. Porque, no Iberê, o óbvio não existe - como também não existia lugar algum no qual achar a cor, a não ser dentro de nós mesmos.

A tarefa determinada para uma semana da bordadeira, me custava três ou quatro horas de trabalho - nas quais afiava a percepçáo e conseguia marcar uma área de um palmo ou pouco mais. E, aquele pouco, demorara toda a semana a ser tecido - após separar e distinguir os fios, acertar o ponto pedido, obedecer ao limite sutil das cores. Cada tapeçaria gastou, em média, seis meses de trabalho. Sou muito grata às mulheres que bordavam - todas com extrema paciência e responsabilidade e que, mesmo sem atinarem o porquê de tantos fios, não se furtavam a obedecer ao que era pedido. $E$, às vezes, ainda ouviam: "meu Deus, não era bem isto -- por favor, desmanche". A tapeçaria pronta ia para a parede. O primeiro momento era de humilhaçáo - como me atrevera a traduzir um Iberê? As transparências, os traços vigorosos - aque le grafismo nervoso - criando relaçăo essencial entre um elemento e outro, como um diálogo, busca de equilíbrio e autenticidade.

A depressão só passava quando ele, com o seu cartáo na mão, examinava atentamente os resultados. As vezes pedia mais um poùco de luz neste ponto - às vezes queria um tom mais alto ou mais baixo nesta cor - outras vezes me perguntava, curioso: "Tiveste de usar este fio?" E eu explicava a dificuldade, a insatisfaçáo que me possúa, e como, dentro de mim, chegara à conclusáo de que aquilo era necessário. E ele: "Está bem, acabe!"

A atitude de Iberê conosco sempre me surpreendeu - pela entrega, confiança e respeito, fazendo com que ele, dono absoluto de suas coisas, fizesse parte, de nossa equipe - numa cumplicidade, sem discriminação pelo papel de cada um. 
Uma tapeçaria possui urdidura ou tela, onde a trama se desenvolve - como a tela do pintor recebe a tinta, ela recebe os fios. É nesta superfície que, pincelada a tinta ou tecidos os fios, buscamos o ponto certo. De alguma forma, penso que, no caso, chegamos lá. As tapeçarias de Iberê Camargo foram expostas e vendidas - no Rio, na Galeria Bonino e, em Porto Alegre, na Galeria Tina Presser. A nossa única frustração foi a de não ter alguma em espaço público, para ser vista por quantos passassem e apreciassem um momento de emoçáo.

Maria Angela de Almeida Magalhâes é artista plástica e tapeceira. 


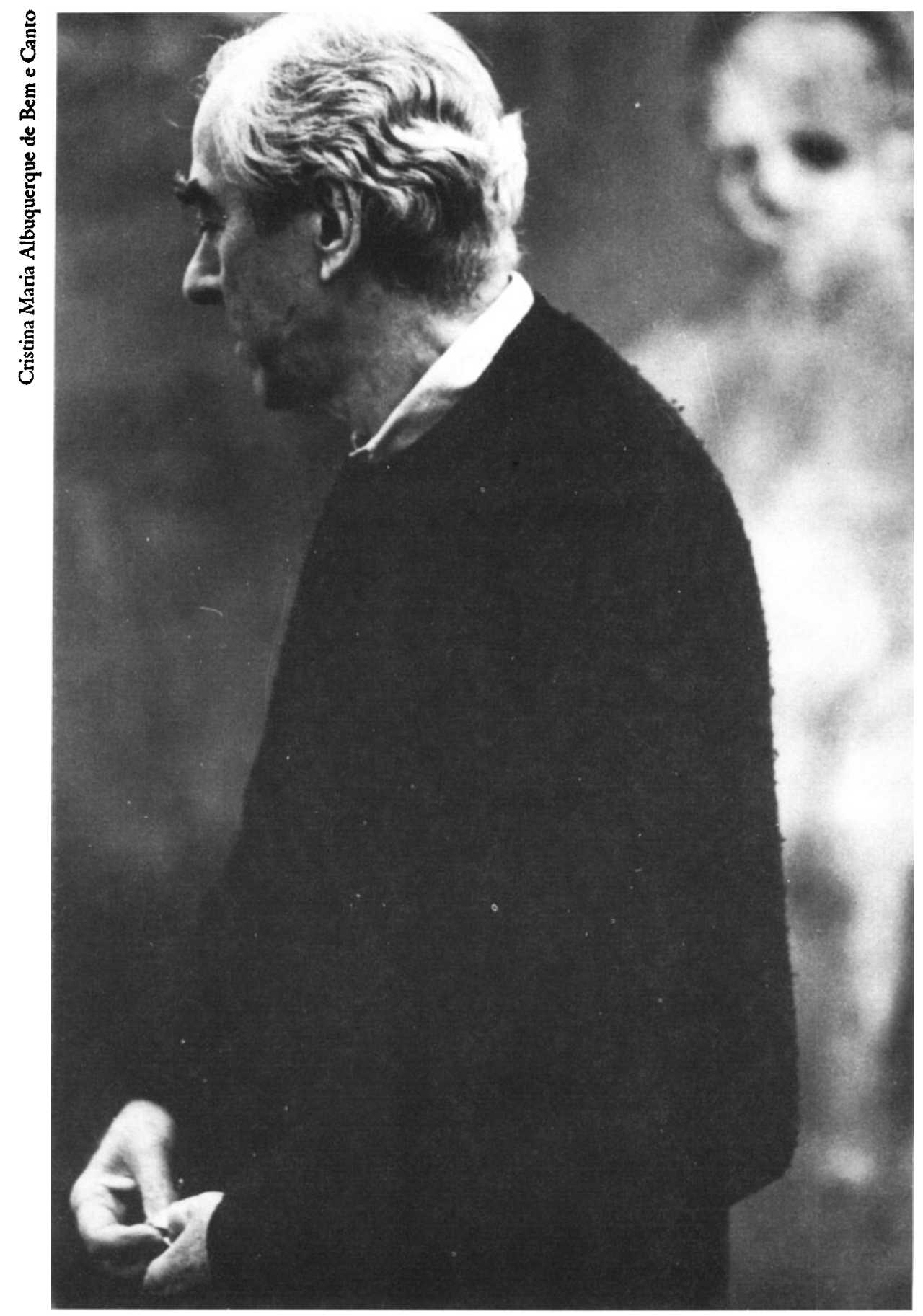

O artista plástico Iberề Camargo em seu atcliê em Porto Alcgre, RS 


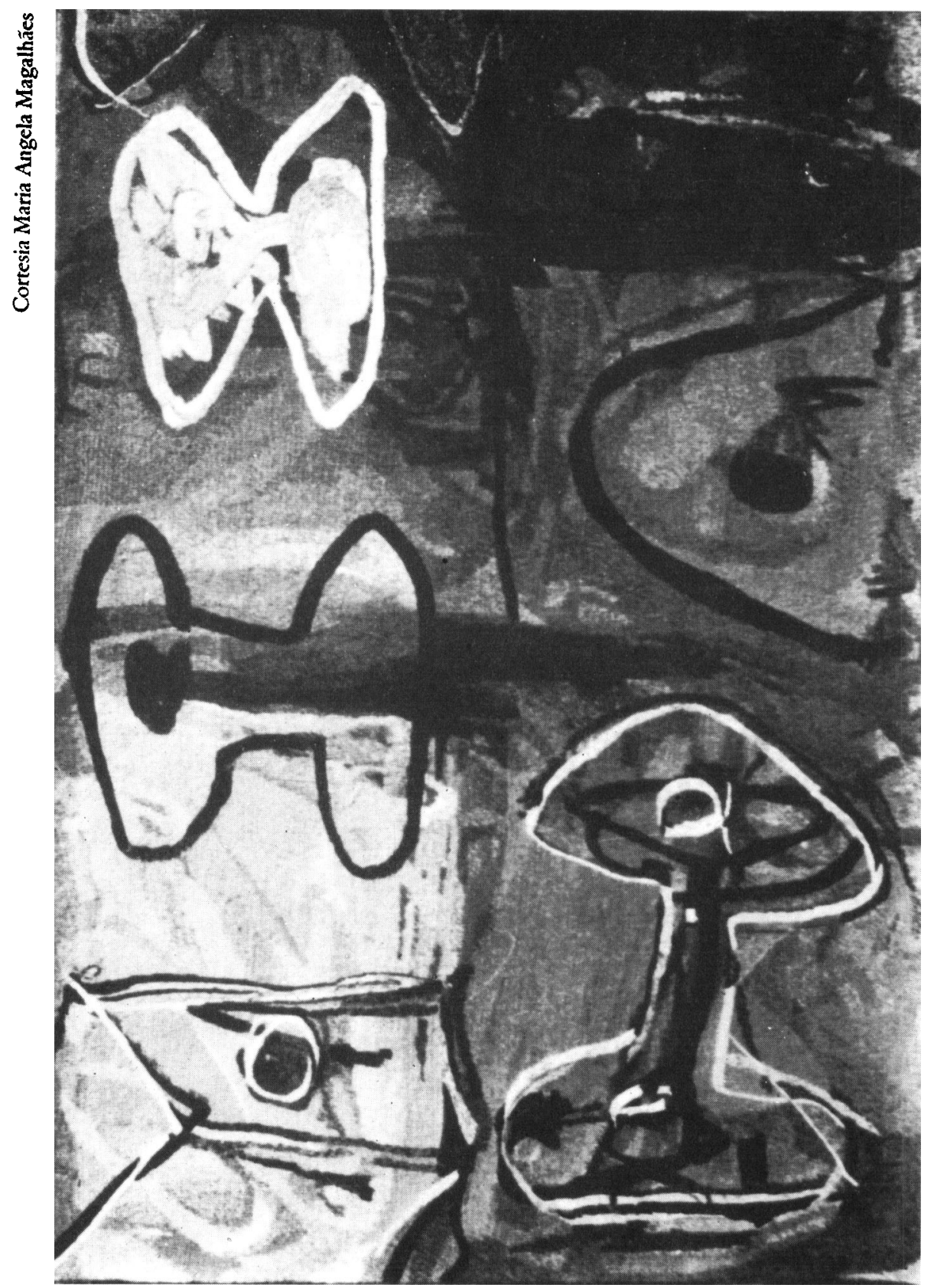

वे 


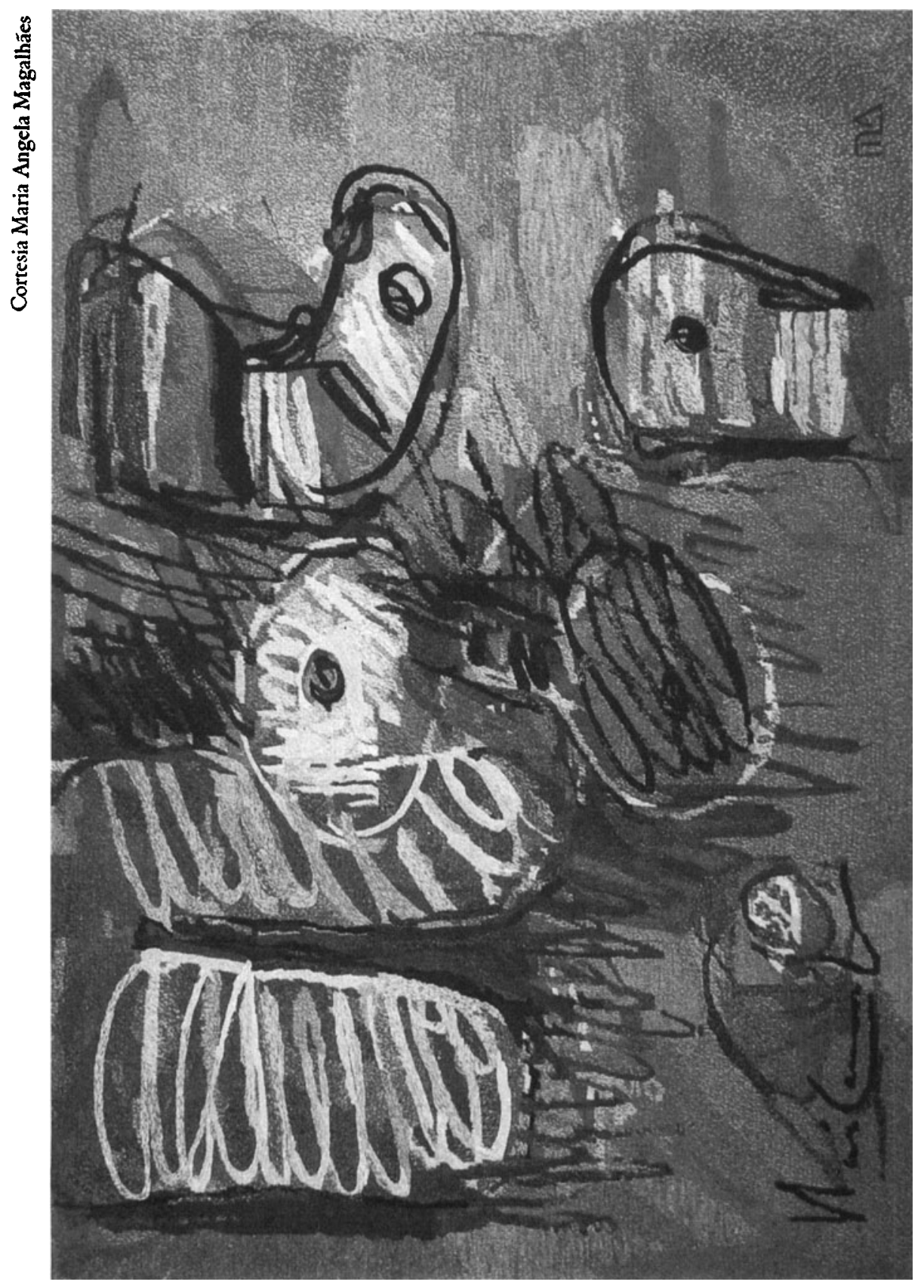

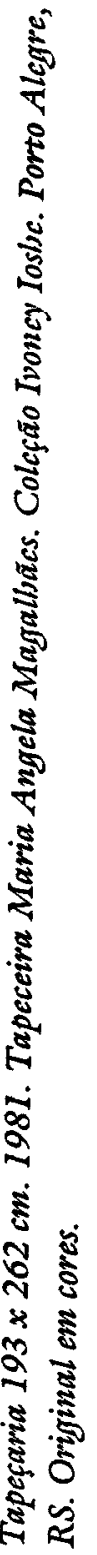

